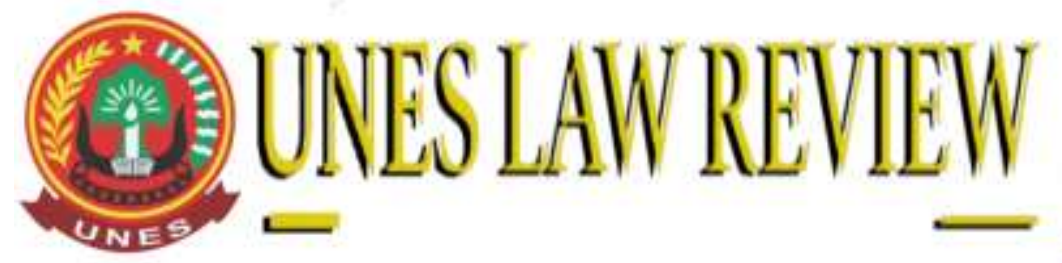

$+6282287504359$

+6282287504359

https://review-unes.com/

uneslawreview@gmail.com

DOI: https://doi.org/10.31933/unesrev.v3i3

Diterima: 17/03/2021, Diperbaiki: 21/05/2021, Diterbitkan: 23/05/2021

\title{
STRATEGI PENETAPAN TERSANGKA DALAM KECELAKAAN LALULINTAS BERAT OLEH PENYIDIK SATUAN LALU LINTAS POLRES AGAM
}

\author{
Bermana Manda \\ Program Magister Ilmu Hukum, Universitas Ekasakti, Padang \\ Email: mandabermana@gmail.com
}

Corresponding Author: Bermana Manda

\begin{abstract}
Obstacles in the Determination of a Suspect in a Traffic Accident by the Agam Traffic Police is that there are no witnesses who saw the accident directly, the witness only knew after the accident had occurred. The number of traffic unit personnel is not proportional to the number of traffic accidents that occur. Lack of infrastructure to support investigations. Often the Traffic Traffic Police are late to the scene of the accident. The strategy for determining a suspect in a traffic accident by the Agam Traffic Police is to conduct the first crime scene (TKP). After the marking, the crime scene measurement and the installation of a police line were taken. The investigator then made a sketch of the accident and engineered the event. Satlantas Polres agam has developed a technology-based system called Rect PC Software and PC Crash. The work of this system starts from the data obtained in the traffic accident scene then processed into a traffic accident reconstruction in 2 (two) dimensional form on the computer. The reconstruction results made through PC Rect and PC Crash software are in the form of evidence in the form of instructions, to prove someone's negligence by seeing whether someone has used the principle of prudence or not.
\end{abstract}

Keywords: Strategy, Traffic Accidents, Investigators, Suspects

\begin{abstract}
ABSTRAK
Kendala Dalam Pelaksanaan Penetapan Tersangka Dalam Kecelakaan Lalulintas Oleh Satlantas Polres Agam adalah tidak adanya saksi yang melihat langsung kejadian kecelakaan, saksi hanya mengetahui setelah kecelakaan terjadi. Jumlah personil Unit laka lantas yang tidak sebanding dengan jumlah kecelakaan lalulintas yang terjadi. Kurangnya sarana prasarana yang mendukung penyidikan, Seringkali Satlantas terlambat menuju tempat terjadinya kecelakaan. Strategi Penetapan Tersangka Dalam Kecelakaan Lalulintas Oleh Satlantas Polres Agam adalah dengan Melakukan Olah Tempat Kejadian Perkara (TKP) pertama. Setelah pemberian tanda dilakukan pengukuran TKP dan pemasangan garis polisi. Penyidik selanjutnya membuat gambar sketsa kecelakaan dan melakukan rekayasa peristiwa. Satlantas Polres agam telah mengembangkan
\end{abstract}


sistem berbasis teknologi yang dinamakan dengan Software PC Rect dan PC Crash. Kerja dari sistem ini dimulai dari data-data yang diperoleh dalam TKP kecelakaan lalulintas kemudian diolah menjadi sebuah rekontruksi kecelakaan lalulintas dalam bentuk 2 (dua) dimensi di komputer. Hasil rekontruksi yang dibuat melalui Software PC Rect dan PC Crash kedudukan dalam alat bukti tersebut berupa petunjuk, untuk membuktikan kealpaan seseorang dengan melihat apakah seseorang itu telah menggunakan prinsip kehati-hatian atau tidak.

Kata Kunci: Strategi, Kecelakaan Lalulintas, Penyidik, Tersangka

\section{PENDAHULUAN}

Upaya untuk meningkatkan kesejahteraan masyarakat seiring kemajuan ilmu pengetahuan dan teknologi, pemerintah Indonesia telah berusaha melaksanakan pembangunan di berbagai bidang. Pembangunan tersebut tidak hanya meliputi pembangunan fisik saja seperti pembangunan gedung, perbaikan jalan, tetapi juga dalam segi kehidupan lain di antaranya meningkatkan keamanan bagi warga masyarakat, karena kehidupan yang aman merupakan salah satu faktor yang mendorong terciptanya kesejahteraan masyarakat, sehingga bila keamanan yang dimaksud bukan berarti tidak ada perang tetapi dapat meliputi keamanan dalam segi yang lain, salah satunya adalah keamanan menggunakan jalan raya dan fasilitas-fasilitas yang ada di jalan raya tersebut.

Menurut Pasal 1 angka 24 Undang Undang Nomor 22 Tahun 2009 tentang Lalu Lintas dan Angkutan Jalan (UU LLAJ), kecelakaan lalu lintas adalah suatu peristiwa di Jalan yang tidak diduga dan tidak disengaja melibatkan Kendaraan dengan atau tanpa Pengguna Jalan lain yang mengakibatkan korban manusia dan/atau kerugian harta benda. Jenis kecelakaan lalu lintas diatur pada Pasal 229 Undang-Undang Nomor 22 Tahun 2009 tentang Lalu Lintas dan Angkutan Jalan yang menggolongkan kecelakaan lalu lintas sebagai berikut Kecelakaan lalin ringan, dan Kecelakaan lalin berat.

Kecelakaan lalin berat adalah yakni kecelakaan yang mengakibatkan korban meninggal dan/atau luka berat. luka berat dimaksud adalah yang mengakibatkan korban jatuh sakit dan tidak ada harapan sembuh sama sekali atau menimbulkan bahaya maut. tidak mampu terus menerus untuk menjalankan tugas jabatan atau pekerjaan. kehilangan salah satu panca indera. menderita cacat berat atau lumpuh. terganggu daya pikir selama 4 (empat) minggu lebih. gugur atau matinya kandungan seseorang. luka yang membutuhkan perawatan rumah sakit lebih dari tiga puluh hari.

Perkara tindak pidana lalu lintas umumnya terjadi tanpa kesengajaan, di sini yang ada hanya unsur kealpaan atau kelalaian. Pengenaan pidana kepada orang yang karena alpa melakukan kejahatan, artinya ada kejahatan yang pada waktu terjadinya keadaan mental seseorang tidak mengetahui dan sama sekali tidak bermaksud untuk melakukan suatu perbuatan, meskipun demikian pelakunya dipandang tetap bertanggung jawab atas terjadinya perkara yang terlarang itu, walaupun sama sekali tidak bermaksud untuk melakukan suatu perbuatan yang ternyata adalah kejahatan.

Polisi lalulintas harus mengadakan penyidikan terhadap perkara kecelakaan lalulintas tersebut. Kegiatan penyidikan dilakukan salah satunya adalah untuk menemukan tersangka, 
sebagimana tercantum dalam Pasal 1 ayat (2) Undang undang Nomor 8 Tahun 1981 tentang Hukum Acara Pidana, Penyidikan adalah serangkaian tindakan penyidik dalam hal dan menurut cara yang diatur dalam undang-undang ini untuk mencari serta mengumpulkan bukti yang dengan bukti itu membuat terang tentang tindak pidana yang terjadi dan guna menemukan tersangkanya.

Menetapkan tersangka menjadi suatu permasalahan dalam perkara kecelakaan lalulintas seperti pada perkara kecelakaan lalulintas yang dilakukan penyidikannya oleh Satlantas Polres agam. Kecelakaan tersebut terjadi pada hari kamis tanggal 1 November 2018, pukul 22.45 Wib bertempat dijorong surau lubuak kenagarian tigo balai kec. matur kab. Agam, terjadi kecelakaan antara pengendara sepeda motor vega nomor Polisi BM 6519 CN yang dikendarai oleh Azwarman dengan pejalan kaki warman. Kecelakaan ini menyebabkan pejalan kaki tersebut meninggal dunia. Setelah dilakukan pemeriksaan terhadap Saksi dan didapat keterangan bahwa mereka tidak melihat langsung kejadian kecelakaan tersebut, namun mereka tahu setelah kejadian dan korban dibawa ke Puskesmas Matur dalam kondisi tidak sadarkan diri dan dirujuk ke RSU Ahmad Mochtar Bukit tinggi.

Permasalahan yang terjadi adalah tidak ada saksi saksi yang melihat langsung kejadian terjadinya kecelakaan yang mengakibatkan Korban Koma dan meninggal dunia. Terhadap permasalah diatas apakah penyidik bisa menentukan pelaku/diduga tersangka dalan tindak pidana Kecelakan lalu lintas tersebut, dikarenakan kekurangan alat bukti.

Berdasarkan latar belakang tersebut, maka permasalahan yang akan diteliti adalah kendala dan strategi dalam pelaksanaan penetapan tersangka dalam kecelakaan lalulintas oleh Penyidik Satlantas Polres Agam.

\section{METODE PENELITIAN}

Spesifikasi penelitian adalah deskriptif analitis, dengan metode pendekatan yuridis normative didukung oleh yuridis empiris. Jenis data yang digunakan adalah data sekunder dan data primer. Data sekunder diperoleh dari studi dokumen, data primer diperoleh dengan cara wawancara. Data yang diperoleh kemudian dianalisa secara kualitatif .

\section{HASIL DAN PEMBAHASAN}

\section{Kendala Dalam Pelaksanaan Penetapan Tersangka Dalam Kecelakaan Lalulintas Oleh Satlantas Polres Agam}

Pada penanganan perkara kecelakaan lalulintas Polisi Lalulintas juga mengalami berbagai kendala terutama pada persoalan penetapan tersangka pada peristiwa kecelakaan lalulintas yang menyebabkan meninggalnya orang. Kendala yang Dihadapi Oleh Polisi Dalam Menegakkan Hukum Berlalu Lintas antara lain tidak adanya saksi yang melihat langsung kejadian kecelakaan, saksi hanya mengetahui setelah kecelakaan terjadi. Keadaan ini mempersulit penyidik dalam menentukan tersangka pada perkara kecelakaan tersebut. Karena apabila tidak ada saksi proses penanganan perkara sudah pasti akan sulit untuk berjalan. Kurangnya kesadaran hukum pada masyarakat yang dimaksud disini adalah dalam hal kesadaran masyarakat untuk membantu penyidik dalam melakukan penyidikan suatu tindak pidana. Kebanyakan masyarakat tidak mau 
tahu atau tidak peduli dengan peristiwa kecelakaan lalulintas yang terjadi. Mereka menolak untuk menjadi saksi dari peristiwa kecelakaan tersebut. Termasuk juga disini adalah sikap masyarakat yang berbondong bonding ke lokasi kecelakaan sehingga dapat menghilangkan jejak peristiwa kecelakaan dan barang bukti yang ada pada lokasi kecelakaan tersebut. Kurangnya kemampuan dari Polisi lalulintas juga menjadi kendala lain dalam proses penetapan tersangka kecelakaan lalulintas.

Sebagaimana yang diharapkan, baik secara kualitas (penguasaan teknis dan taktis penyidikan) maupun kuantitas (ratio ketersediaan aparat penyidik dengan kasus yang ditangani serta penyebaran jumlah penyidik). Selain itu, kelemahan sumber daya manusia dapat pula muncul dari aspek kultural yaitu sikap-sikap aparat penyidik yang arogan, tidak memiliki sifat melayani, manipulatif, diskriminatif dan sebagainya. Apabila penegak hukum dianggap sebagai orang yang paling mengetahui akan suatu aturan, dengan demikian apa yang dilakukan aparat penegak hukum, maka akan menjadi teladan bagi masyarakat.

Dalam melakukan olah TKP, Satuan Lalu lintas hanya bisa menurunkan jumlah personil yang sedikit, karena dalam unit laka hanya memiliki personil sebanyak 11 orang termasuk di dalamnya kasatlantas dan kanitlaka. Tidak hanya itu jumlah penyidik juga sangat terbatas yakni hanya berjumlah 4 orang yang terdiri dari 2 orang penydik pembantu. Jumlah ini jelas sekali tidak sebanding dengan jumlah perkara laka lantas yang terjadi di Wilayah Kabupaten Agam. Jumlah ini tentunya tidak mencukupi untuk menangani seluruh permasalahan penyidikan perkara-perkara laka lantas dan upaya-upaya penanggulangannya. Jika dibandingkan dengan unit lain seperti SAMSAT dan unit SIM yang memiliki jumlah personil yang banyak, sementara permasalahan yang dihadapi tidak begitu banyak dan tidak rumit. Dengan perkataan lain, proporsi jumlah personil yang bertugas dibandingkan kuantitas dan kualitas masalah yang ditangani tidak proporsional.

Akibatnya penegakan hukum yang berwujud penyidikan menjadi tidak terlaksana dengan baik. Kurangnya sarana prasarana yang mendukung Banyaknya sarana lalu lintas yang terpasang dijalan seperti lampu apill yang rusak sehingga tidak menyala maka dapat mengganggu kelancaran lalu lintas, menimbulkan banyak masyarakat melakukan pelanggaran dan tidak ada yang mau mengalah. Rambu, plang dan aturan lalu lintas yang dibuat oleh polisi tidak sesuai isi Undang Undang Nomor 2 tahun 2002. Dalam prasarana seperti kurangnya pengadaan pos polisi termasuk adanya penjaga dalam pos tersebut kadang dibiarkan kosong tidak terpakai. Pendanaan yang diberikan pemerintah tidak diwujudkan oleh yang berwenang untuk membuat sarana dan prasarana lalu lintas yang lengkap supaya masyarakat dapat nyaman di jalan raya. Kondisi yang ditemui di lapangan berdasarkan wawancara dengan penyidik pada Satlantas Polres Agam mengatakan bahwa Seringkali kami terlambat menuju tempat terjadinya kecelakan, karena memang kendaran yang kami miliki tidaklah mendukung, ditambah lagi kondisi jalan yang tidak mendukung pula, akibatnya sering kali tempat kejadian perkara (TKP) sudah di evakuasi oleh orang yang melihat kecelakan tersebut atau warga yang berada dekat dengan tempat terjadinya kecelakan. Padahal dalam Standar operasional prosedur (SOP) lakalantas seharusnya jika terjadi 
kecelakan lalu lintas Polisi lalu lintas wajib datang dalam waktu sekurang-kurangnya 30 menit sudah sampai Di tempat kejadian perkara.

\section{Strategi Penetapan Tersangka Dalam Kecelakaan Lalulintas Berat Oleh Satlantas Polres Agam}

Adapun adalah pelaksanan Penyelidikan dan penyidikan yang dilakukan oleh Satuan Lalu Lintas adalah diawali dengan pelaksanaan Penyelidikan. Penyelidikan adalah upaya yang pertama yang dilakukan dalam polisi lalu lintas dalam melaksanakan tugas pokoknya jika terjadi suatu kecelakaan yang mengakibatkan orang lain meninggal dunia. Sebagaimana Pasal 1 angka 5 KUHP menyebutkan bahwa penyelidikan adalah tindakan penyelidik untuk mencari dan menemukan peristiwa yang diduga sebagai tindak pidana guna menentukan dapat atau tidaknya dilakukan penyidikan menurut cara yang diatur dalam Undang-Undang ini.

Pelaksanaan Penyidikan Menurut pasal 1 angka 3 KUHP Penyidikan adalah dalam hal menurut cara yang diatur dalam Undang-Undang ini untuk mencari dan mengumpulkan bukti yang dengan bukti itu membuat terang tindak pidana yang terjadi dan menemukan tersangka. Pada perkara kecelakaan lalulintas, persoalan yang timbul adalah dalam hal menetapkan tersangka pada peristiwa tersebut.

Penyidik harus secara cermat melakukan analisa berdasarkan bukti yang ada tentang siapa tersangka pada perkara tersebut. Karena terkadang korban adalah tersangka dalam peristiwa kecelakaan lalulintas jadi tidak mutlak orang yang masih selamat yang terlibat dalam kecelakaan tersebut yang merupakan tersangka. Sering dalam suatu perkara kecelakaan lalulintas tidak ada saksi yang melihat langsung bagaimana kecelakaan tersebut terjadi.

Guna menemukan tersangka langkah yang dilakukan dalam rangka penyidikan terhadap kecelakaan yang mengakibatkan orang lain meninggal dunia adalah yang Melakukan Olah Tempat Kejadian Perkara (TKP) pertama. Dalam hal ini penyidik melakukan olah TKP untuk dapat menentukan bagaimana terjadinya kecelakaan tersebut dengan memberikan tanda ditempat ditemukannya korban dan barang bukti. Setelah pemberian tanda dilakukan pengukuran TKP dan pemasangan garis polisi. Untuk mempermudah penyidikan, penyidik membuat gambar sketsa kecelakaan dan melakukan rekayasa peristiwa. Hal ini dilakukan dengan tujuan untuk memperoleh kejelasan peristiwa, bagaimana kecelakaan tersebut dapat terjadi, siapa yang menjadi korban dan pelaku, berapa orang yang menjadi korban, menafsirkan berapa kerugian material yang di derita, dan sejauh mana penyidikan dapat dilakukan.

Dalam olah TKP kecelakaan lalulintas, memperoleh barang bukti yang digunakan untuk penyidikan selanjutnya. Barang bukti menurut Andi Hamzah adalah barang bukti mengenai mana delik tersebut dilakukan (objek delik) dan barang dengan mana delik dilakukan (alat yang dipakai untuk melakukan delik), termasuk juga barang yang merupakan hasil dari suatu delik Ciri-ciri benda yang dapat menjadi barang bukti; a. Merupakan objek materiil; b. Berbicara untuk diri sendiri; c. Sarana pembuktian yang paling bernilai dibandingkan sarana pembuktian lainnya; dan d. Harus diidentifikasi dengan keterangan saksi dan keterangan terdakwa. 
Mengacu pada pendapat tersebut maka barang bukti yang diperoleh di TKP kecelakaan lalulintas selain kendaraan bermotor yang terlibat kecelakaan juga harus mengambil gambar/foto yang diambil dari TKP.

Pada saat ini Polri telah mengembangkan sistem berbasis teknologi yang dinamakan dengan Software PC Rect dan PC Crash. Kerja dari sistem ini dimulai dari data-data yang diperoleh dalam TKP kecelakaan lalulintas kemudian diolah menjadi sebuah rekontruksi kecelakaan lalulintas dalam bentuk 2 (dua) dimensi di komputer. Alat untuk merekontruksi tersebut dinamakan dengan Software PC Rect dan PC Crash. Rekonstruksi yang diperoleh dalam fase sebelum benturan (pre crash), saat benturan (crash) dan setelah benturan (posh crash). Fungsi dari Software PC Rect dan PC Crash adalah mengolah barang bukti menjadi alat bukti.

Pengertian alat bukti Pasal 184 ayat (1) Kitab Undang-Undang Hukum Acara Pidana ("KUHAP") disebutkan bahwa alat bukti yang sah adalah: keterangan saksi, keterangan ahli, surat, petunjuk dan keterangan terdakwa. Dalam sistem pembuktian hukum acara pidana yang menganut stelsel negatief wettelijk, hanya alat-alat bukti yang sah menurut undangundang yang dapat dipergunakan untuk pembuktian. Mengacu pada pengertian ini maka hasil rekontruksi 3 (tiga) dimensi yang dibuat melalui Software PC Rect dan PC Crash kedudukan dalam alat bukti tersebut berupa "Petunjuk". Petunjuk adalah perbuatan, kejadian atau keadaan yang karena persesuaiannya, baik antara yang satu dengan yang lain, maupun dengan tindak pidana itu sendiri. Menandakan bahwa telah terjadi suatu tindak pidana dan siapa pelakunya (Pasal 188 (1) KUHAP). Dalam HIR pasal 310 yang dimaksud dengan petunjuk-petunjuk adalah perbuatanperbuatan, kejadian-kejadian atau hal-hal yang ada persesuaiannya baik satu sama lain maupun dengan perbuatan yang dituduhkan terhadap terdakwa dapat menunjukkan dengan nyata bahwa suatu kejahatan telah dilakukan dan siapa yang melakukannya.

Dengan adanya petunjuk yang jelas terkait suatu kecelakaan lalulintas, maka akan memudahkan proses peradilan (penyidikan, penuntutan dan vonis pengadilan), karena terdapat kejelasan dalam melihat peristiwa kecelakaan yang terjadi, terlihat jelas posisi pengemudi kendaraan mana yang melanggar aturan yang ada. Pembuktian kecelakaan lalulintas memanfaatkan perkembangan teknologi, menggunakan Software PC Rect dan PC Crash, diharapkan akan berpengaruh pada peningkatan kinerja penyidik laka lantas, karena mampu menggambarkan dengan jelas sebuah peristiwa kecelakaan. Baik pada fase pre cras, crash maupun posh crash, sehingga diketahui pelanggaran yang menjadi penyebab dalam peristiwa kecelakaan lalulintas tersebut.

Penentuan pihak yang bertanggungjawab dalam sebuah kecelakaan sesuai dengan peristiwa, menunjukan bahwa telah terwujud suatu kepastian hukum dalam penyidikan kecelakaan lalulintas. Setelah terjadinya kecelakaan lalu lintas tentunya Polisi harus segera melakukan penindakan kepada pelaku terjadinya kecelakaan yaitu dengan melakukan penangkapan. Hal ini bertujuan agar pelaku tidak pergi meninggalkan TKP atau berusaha melarikan diri. Penangkapan terhadap pelaku tindak pidana kelalaian yang mengakibatkan orang lain meninggal dunia adalah suatu tindakan penyidik berupa penangkapan sementara waktu kebebasan tersangka apabila telah terdapat cukup bukti, guna kepentingan penyidikan. Sesuai 
dengan kewajiban penyidik yang disebutkan pada Pasal 7 huruf D bahwa penyidik berwenang untuk melakukan penangkapan, penahanan, penggeledahan, dan penyitaan.

Apabila dilihat dari Perkara Laporan Polisi Nomor : LP/162/ XI / LL / 2018, tanggal 02 November 2018. Dan Perkara Laporan Polisi Nomor : LP / 75 / IIV / LL / 2019, tanggal 01 Juli 2019 sesuai dengan proses penanganan perkara kecelakaan lalu lintas dan dari teori yang ada untuk membuktikan kealpaan seseorang adalah dengan melihat apakah seseorang itu telah menggunakan prinsip kehatihatian atau tidak, melihat bagaimana orang pada umumnya melakukan tindakan apabila dalam kondisi seperti yang dialami oleh pelaku dan apakah seseorang itu sudah melakukan tindakan yang seharusnya dilakukan atau belum.

Apabila dilihat melalui unsur-unsur kealpaan bahwa tersangka dalam perkara nomor 162 disini sudah mengendari kendaraannya dengan benar dan kemungkinan besar tidak ada akibat yang timbul dari dia berkendara karena sudah dalam posisi yang benar. Hanya karena factor cuaca yang berkabut gelap pada malam hari serta kondisi jalan dimana ada tanggul yang dipasang dijalan tersebut. Karena ada tanggul maka tersangka mengambil jalan lebih ke pinggir kiri dan ternyata ada pejalan kaki disana yang tidak terlihat oleh tersangka. Hal ini juga sudah menghindarkan diri dari sifat melawan hukum serta Tersangka tidak dapat dipersalahkan atas apa yang dilakukan. Sementara korban juga berjalan terlalu ke tengah jalan karena kondisi pada malam hari dan tidak menghiraukan adanya kendaraan lain yang akan melintas.

Melihat dari sini bahwa unsur unsur kealpaan sudah tidak dipenuhi oleh Tersangka dan justru dipenuhi oleh korban sebagai syarat adanya pemidanaan. Maka dari itu yang dapat di persangkakan melakukan tindak pidana adalah korban sendiri. Karena yang terbukti menjadi Tersangka adalah korban yang sudah meninggal, Penyidik harus mengeluarkan SP3 atau disebut sebagai surat penghentian Penyidikan.

Penanganan perkara juga harus lebih selektif dan teliti lagi untuk menetapkan status tersangka karena menurut fakta yang ada bahwa ternyata proses penanganan kecelakaan lalu lintas di Kepolisian tidak lebih dari 7 hari. Berbeda dengan Perkara Laporan Polisi Nomor : LP / 75 / IIV / LL / 2019, tanggal 01 Juli 2019, meskipun kronologi kasusnya yang terdapat pada fakta-fakta hasil olah TKP ditemukan bahwa tidak ada prinsip kehatihatian yang dilakukan oleh Tersangka sehingga membahayakan pengendara lainnya. Penyidik Kepolisian dalam melakukan pembuktian terkait dengan dugaan bahwa Tersangka melakukan kealpaan dilakukan dengan melihat olah TKP. Tidak hanya olah TKP saja Penyidik juga melihat apakah pengendara sudah menggunakan prinsip kehatihatian atau belum. Pada perkara ini tersangka mengakui sedang berada dalam kondisi mengantuk dan tertidur sehingga tidak melihat adanya pejalan kaki yang berada di sisi jalan. Berdasarkan penyidikan juga ditemukan bahwa tersangka tidak ada upaya untuk menghindari terjadinya kecelakaan karena terbukti tidak ada jejak erm di lokasi kejadian. Ukuran hati-hati ini dilihat dari jarak pengendara dengan pengendara lainnya, kecepatan yang digunakan oleh pengendara, apakah pengendara sudah mematuhi rambu-rambu lalu lintas atau belum serta adakah perhatian yang dilakukan oleh pengendara terhadap situasi di sekelilingnya.

Penyidik dalam menentukan seseorang menjadi Tersangka harus di dasari dengan buktibukti yang cukup. Bukti-bukti yang dimaksud selain melihat dari Sket TKP dan keterangan 
saksi, Penyidik juga melihat dari pemenuhan unsurunsur Pasal yang dikenakan kepada Tersangka. Pengumpulan bukti yang cukup juga harus memperhitungkan batas waktu dilakukannya penyidikan.

Guna menangani suatu perkara kecelakaan lalu lintas hingga mengakibatkan matinya seseorang apabila Penyidik sudah menetapkan seseorang menjadi Tersangka tidak langsung dilimpahkan ke Kejaksaan. Penyidik masih memberikan kesempatan untuk dilakukan proses penyelsesaian perkara di luar Pengadilan dengan jalan musyawarah atau mediasi atas kesepakatan kedua belah pihak. Meskipun musyawarah untuk ganti rugi ini wajib diberikan oleh pihak Tersangka dengan tidak menggugurkan tuntutan perkara pidana.

\section{PENUTUP}

Peningkatan ketersediaan sarana dan prasarana dalam melakukan penyidikan tindak pidana kecelakaan lalulintas, sehingga penegakan hukumnya dapat dilakukan dengan sebaik mungkin. Serta aparat Penegak Hukum, sebaiknya harus lebih teliti lagi dalam memeriksa perkara kecelakaan lalu lintas dan lebih mahir dalam memanfaatkan teknologi yang ada.

\section{DAFTAR PUSTAKA}

C.S.T. Kansil dan Christine S.T. Kansil, Disiplin Berlalu Lintas di Jalan Raya, Rineka Cipta, Jakarta, 1995

Warpani P Suwardjoko, Keselamatan Lalu Lintas, Simpusium ke-4 FSTPT, Universitas Udayana, Bali, 2001.

Andi Hamzah, Hukum Acara Pidana, Alumni, Bandung, 2001

Martiman Prodjohamidjojo, Sistem Pembuktian dan Alat-alat Bukti, Liberty, Yogayakarta, 1994 